\title{
Lipoprotein (a) level in pre-eclampsia patients
}

\author{
Saila Parvin ${ }^{1}$, Latifa Samsuddin ${ }^{2}$, Ahammed $\mathrm{Ali}^{3}$, Shafiqul Alam Chowdhury ${ }^{4}$, Ibrahim Siddique ${ }^{5}$ \\ ${ }^{1}$ Department of Gynaecological Oncology, NICRH, Dhaka, ${ }^{2}$ Department of Obstetrics and \\ Gynaecology, Enam Medical College, ${ }^{3}$ Department of Skin and VD, ShSMCH, \\ ${ }^{4}$ Department of Urology, DMCH, ${ }^{5}$ Department of Surgery, BSMMU
}

\begin{abstract}
This study was carried in BSMMU from July 2001 to June 2003. During the study period, 60 pregnant women were studied. Thirty patients were preeclamptic and thirty were normal healthy pregnant women served as control. Serum lipoprotein(a) was found significantly higher in preeclamptic women $56.63 \pm 22.6 \mathrm{mg} / \mathrm{dl}$ and found within limit in normal healthy pregnant women, $12.89 \pm 4.59 \mathrm{mg} / \mathrm{dl}$. Result is statistically highly significant $(\mathrm{P}<0.001)$. Mean Systolic Blood Pressure was $163.33 \pm 29.63 \mathrm{mmHg}$ and $117.00 \pm 11.19 \mathrm{mmHg}$ in case and control and Diastolic Blood Pressure was $108.53 \pm 14.54 \mathrm{mmHg}$ and $76.00 \pm 6.87 \mathrm{mmHg}$ respectively in case and control group. Result was highly significant as P $<0.001$. The mean $( \pm \mathrm{SD})$ serum lipoprotein(a) concentration in normal pregnancies and preeclampsia were found to be $12.91 \pm 4.94$ and $56.65 \pm 22.62$. Moderate Proteinuria was found in $77.5 \%$ and severe proteinuria in $22.2 \%$ cases of preeclampsia respectively. Regardless of mechanism and pathophysiology of preeclampsia, we found high serum level of lipoprotein (a) in preeclampsia patients. These high levels of lipoprotein (a) significantly correlated with blood pressure and proteinuria.
\end{abstract}

\section{Introduction}

Preeclampsia in hypertension associated with proteinuria $\geq 300 \mathrm{mg}$ in 24 hours urine or $\mathrm{Igm} / \mathrm{L}$ in any random sample of urine and with or without oedema occurring primarily in nulliparous women after the $2^{\text {nd }}$ half of gestation and most frequently near term. Sometimes this turn into essential hypertension ${ }^{1}$. Preeclampsia occurs in about 5 to 15 percent of the general population ${ }^{2}$.

Characteristic features of severe preeclampsia ${ }^{3}-$ 1) Blood pressure greater than $164 \mathrm{mmHg}$. 2) Proteinuria exceeding $2 \mathrm{gm}$ in a $24-$ hours, 3) Creatinine $(>1.2 \mathrm{mg} / \mathrm{df}), 4)$ Oliguria $<500 \mathrm{ml} 24$ hours, 5) Cerebral or visual disturbance, Epigastric pain, 7) Elevated liver enzyme, 8) Platelet count $<100,000 / \mathrm{mm}^{3}$, 9) Retinal haemorrhage, exudate or papillodema, 10), Pulmonary oedema.

Genetic factors seems to be important in the aetiology of preeclampsia ${ }^{4}$ preeclampsia is postulated to be caused by insufficient causing a compromised placental circulation ${ }^{5}$.

Preeclampsia is a serious complication of the second half of pregnancy that occurs with a frequency of upto 15 percent $^{2}$.

Altered coaguability may be important in the pathogenesis of preeclampsia. This study has been designed to measure and analyze the concentrations of lipoprotein (a) level in maternal serum, to find out its significance in the pathogenesis of preeclampsia.

\section{Aims and Objective}

\section{General Objectives:}

Lipoprotein (a) level are elevated in preeclampsia patients and associated with severity of the disease. On the basis of the above hypothesis; a case control study with the aim to determine the role of liproprotein (a) in the pathogenesis of preeclampsia was done.

Specific Objectives:

a) To determine the level of serum lipoprotein(a) in preeclampsia patients.

b) To determine the association of raised lipoprotein(a) with the severity of preeclampsia

c) To evaluate; its usefulness in screening for preeclampsia.

\section{Materials and Methods}

This is a case control prospective, consecutive, cross sectional observational study. Study period is July 2001 to June 2003.

\section{Study Subjects}

This study included 60 pregnant women, selected consecutively from among the patients attending the Department of Obstetrics and Gynecology, BSMMU and DMCH, during the study period. The 
women were divided into two group: (a) case $(\mathrm{n}=30)$ and $(\mathrm{b})$ control $(\mathrm{n}=30)$.

Inclusion criteria:

- Preeclampsia patient means hypertension with proteinuria with or without oedema appearing in pregnant patient after 20 weeks of pregnancy.

- Hypertension means systolic blood pressure $>140$ $\mathrm{mm}$ of $\mathrm{Hg}$ and diastolic blood $>90 \mathrm{~mm}$ of $\mathrm{Hg}$ on two occasion at least 6 hours apart.

- Proteinuria may be defined as $\geq 300 \mathrm{mg}$ albumin in urine in 24 hours urine or $1 \mathrm{gm} / \mathrm{L}$ of urine in any sample.

- Mild proteinuria : e.g. +albumin,

- Moderate proteinuria : e.g. ++ albumin

- Severe proteinuria: e.g. +++ albumin

- Preeclampsia is of two degree mild and severe depending on diastolic blood pressure.

- Mild preeclampsia that is diastolic blood pressure is $<110 \mathrm{~mm}$ of $\mathrm{Hg}$.

- Severe preeclampsia that is diastolic blood is > $110 \mathrm{~mm}$ of $\mathrm{Hg}$.

a) For case

1. Pregnant women, 28 to 42 weeks gestation

2. Hypertension and Proteinuria present

3. Body weight 45 to $80 \mathrm{~kg}$

b) For control

1. Pregnant women, 28 to 42 weeks gestation

2. No hypertension or Proteinuria present

3. Body weight 45 to $80 \mathrm{~kg}$.

Age:

- Age ranging from 18 to 30 years in control and 18 to 32 years in case group.

- Age range of control group is $23.40 \pm 3.04$ years and case group $23.73 \pm 4.33$ year as similar age group of case and control will be easier to compare and above mentioned age group of pregnant patient is available and beyond these age group are not available. If available they had other disease associated.

Height: Height ranged from 144 to $155 \mathrm{~cm}$ in control group and from 132 to $165 \mathrm{~cm}$ in case group.

Gravida: Gravidity of the patients were recorded.

Blood pressure: (both systolic and diastolic) were measured in a supine position.

Exclusion criteria:

a. Patients with known renal disease

b. Patients with diabetes mellitus

c. Diagnosed patients of hepatic dysfunction

d. Patients in labour

e. Patients using diuretics

Procedure of proteinuria detection: Urinary protein that is proteinuria is detected by dip stick method.

Sample collection for serum lipoprotein(a) detection: For lipoprotein(a) from each subject (both case and control), $5 \mathrm{ml}$ of venous blood was collected in the morning in fasting state, using sterile disposable plastic syringe, by antecubital venipuncture, taking full aseptic precaution and poured into a clean dry glass test tube. Serum from 30 normal and 30 preeclampsia patients were prepared at BSMMU and DMCH and kept under $40^{\circ} \mathrm{C}$ at BIRDEM until analyzed for serum $\mathrm{Lp}(\mathrm{a})$ level by special lipoprotein assay kit.

Serum Lp(a) levels were assayed by Nephelometer agglutination measurement using special Lp(a) assay kit. This method is based on Ag-Ab reaction.

All relevant collected data were complied on a master chart first, then organized by using scientific calculator and statistical analysis was done by using computer based software SPSS. Here Chi-square and unpaired Student's ' $t$ ' test were done to find out probability value.

\section{Observations \& Results}

Table I: Comparison of clinical biochemical parameter between control and case

\begin{tabular}{lccc}
\hline \multicolumn{1}{c}{ Parameter } & $\begin{array}{c}\text { Control }(\mathrm{n}=30) \\
\text { Mean } \pm \text { SD }\end{array}$ & $\begin{array}{c}\text { Case } \mathrm{n}=30 \\
\text { Mean } \pm \text { SD }\end{array}$ & P value $^{\mathrm{a}}$ \\
\hline Age (years) & $23.40 \pm 3.04$ & $23.73 \pm 4.33$ & $0.731^{\mathrm{NS}}$ \\
Height (cm) & $149.80 \pm 2.81$ & $148.07 \pm 4.89$ & $0.422^{\mathrm{NS}}$ \\
Weight (kg) & $55.87 \pm 5.82$ & $57.17 \pm 9.82$ & $0.000^{*}$ \\
Gestation age (week) & $37.67 \pm 3.00$ & $34.10 \pm 3.52$ & $0.000^{*}$ \\
$\begin{array}{l}\text { Systolic blood pressure } \\
\text { (mmHg) }\end{array}$ & $117.00 \pm 11.19$ & $163.33 \pm 29.63$ & $0.000^{*}$ \\
$\begin{array}{l}\text { Diastolic blood } \\
\text { pressure (mmHg) }\end{array}$ & $76.00 \pm 6.87$ & $108.53 \pm 14.54$ & $0.000^{*}$ \\
Serum lipoprotein (a) & $12.91 \pm 4.94$ & $56.65 \pm 22.62$ & $0.000^{*}$ \\
\hline
\end{tabular}

Unpaired student's ' $t$ ' test, ${ }^{\text {NS }}$ Not significant, $*$ Significant at $\mathrm{P}<0.001$

Table II: Status of proteinuria in the study subject

\begin{tabular}{lccc}
\hline Proteinuira & $\begin{array}{c}\text { Control } \\
(\mathrm{n}=30) \text { No. }(\%)\end{array}$ & $\begin{array}{c}\text { Case } \\
(\mathrm{n}=30) \text { No. }(\%)\end{array}$ & P value $^{\mathrm{a}}$ \\
\hline Moderate & 0 & $21(77.5)$ & $<0.000^{*}$ \\
Severe & 0 & $9(22.5)$ & \\
Nil & $30(100.0)$ & 0 & \\
${ }^{\mathrm{a}}$ Chi-square test, $*$ Significant at $\mathrm{P}<0.001$ & &
\end{tabular}

Table III: Status of oedema in the study subject

\begin{tabular}{lccc}
\hline Oedema & $\begin{array}{c}\text { Control } \\
(\mathrm{n}=30) \text { No. }(\%)\end{array}$ & $\begin{array}{c}\text { Case } \\
(\mathrm{n}=30) \text { No. }(\%)\end{array}$ & $\mathrm{P}$ value $^{\mathrm{a}}$ \\
\hline Mild & $20(66.67)$ & $1(3.33)$ & \\
Moderate & 0 & $19(63.33)$ & \\
Severe & 0 & $10(33.34)$ & $<0.000^{*}$ \\
Absent & $10(33.33)$ & 0 & \\
\hline${ }^{\mathrm{a}}$ Chi-square test, ${ }^{*}$ Significant at $\mathrm{P}<0.001$ & &
\end{tabular}

Table IV: Relationship between serum lipoprotein(a) and systolic blood pressure

\begin{tabular}{lccl}
\hline Group & $\mathrm{n}$ & $\mathrm{r}$ Value & $\mathrm{P}$ value \\
\hline Control & 30 & +0.031 & $0.870^{\mathrm{NS}}$ \\
Case & 30 & 0.0192 & $0.309^{\mathrm{NS}}$ \\
\hline
\end{tabular}

${ }^{\mathrm{NS}}$ Not significant

Table-V: Relationship between serum lipoprotein(a) and diastolic blood pressure

\begin{tabular}{lccl}
\hline Group & $\mathrm{n}$ & $\mathrm{r}$ Value & $\mathrm{P}$ value \\
\hline Control & 30 & +0.129 & $0.498^{\mathrm{NS}}$ \\
Case & 30 & 0.197 & $0.296^{\mathrm{NS}}$ \\
\hline
\end{tabular}

$\frac{\text { Case }}{{ }^{N S} \text { Not significant }}$ 
Table VI: Status of parity in the study subjects

\begin{tabular}{lccc}
\hline Parity & $\begin{array}{c}\text { Control } \\
(\mathrm{n}=30) \text { No. }(\%)\end{array}$ & $\begin{array}{c}\text { Case } \\
(\mathrm{n}=30) \text { No. }(\%)\end{array}$ & P value $^{\mathrm{a}}$ \\
\hline 0 & $8(26.7)$ & $19(63.3)$ & \\
1 & $12(40.0)$ & $4(13.3)$ & \\
2 & $7(23.3)$ & $3(10.0)$ & $0.053^{\mathrm{NS}}$ \\
3 & $2(6.7)$ & $1(3.3)$ & \\
$\geq 4$ & $1(2.3)$ & $3(10.0)$ & \\
\hline Unpaired student' 's 't' test, ${ }^{\text {NS }}$ Not significant
\end{tabular}

\section{Discussion}

The present study dealt with a significant number $(n=30)$ of preeclampsia case where high serum lipoprotein (a) level, i.e. more than $30 \mathrm{mgld}$, which has been set as a cut -Off level, associated with increased of thrombosis and atherosclerosis. ${ }^{7}$ None of the normal pregnant women had lipoprotein level more than $30 \mathrm{mg} / \mathrm{dl}$.

In a study on pregnant women showed serum lipoprotein. (a) level as $7.8 \mathrm{mg} / \mathrm{dl}$ in control (normal pregnancy), $15.77 \mathrm{mg} / \mathrm{dl}$ in women with mild preeclampsia and $82.69 \mathrm{mg} / \mathrm{dl}$ in women with severe preeclampsia. ${ }^{2}$ In our study the serum liproprotein(a) level was $12.91 \pm 4.94 \mathrm{mg} / \mathrm{dl}$ in normal pregnancy and $56.65 \pm 22.62 \mathrm{mg} / \mathrm{dl}$ in preeclamptic women.

A rise in blood pressure is the most important clinical criteria to preeclampsia. The result of correlative analysis between serum lipoprotein (a) and their corresponding systolic and diastolic blood, pressure among preeclampsia cases as well as among total study population suggested the significance of high serum lipoprotein (a) in the pathogenesis of preeclampsia. The direct relation between serum lipoprotein (a) and blood pressure obtained in this study corroborate with the hypothesis that increased serum lipoprotein (a) leads to preeclampsia. Among, with rise of systolic and diastolic blood pressure, there is also of serum lipoprotein (a). So, there is direct correlation between severity of preeclampsia and serum lipoprotein(a) level. So, high serum lipoprotein (a) is associated with severity of preeclampsia. Though statistical result do not necessarily reflect, that occurs in vivo the finding in this study indicate a significant role of increased serum lipoprotein(a) in preeclampsia.

Conclusion: From the results of this study, it appears that raised level of serum lipoprotein(a) occur in pregnant patients with preeclampsia. At this time, we do not know the exact mechanism of high serum level of lipoprotein(a). Moreover, this study did not show why this high level of lipoprotein(a) play central role to the pathophysiology of preeclampsia. Regardless of we mechanism and pathophysiology of preeclampsia, found high serum level of lipoprotein (a) in preeclampsia patients. These high levels of lipoprotein (a) significantly correlated with blood pressure and proteinuria. Further prospective studies are needed to determine whether a rise in serum lipoprotein(a) can be used as an early predictor of the disease.

\section{References}

1. Reynolds C, Marie WC Sinai BM. Hypertensive states of pregnancy. In: DeCherny AK, Nathan L. eds. Current obstetrics and gynecologic diagnosis and treatment. $9^{\text {th }}$ ed. New York: McGraw-Hill; 2003. p. 338.

2. Wang J, Mimurn S, Labour R, Trudinger B, Wang XL. Elevated levels of lipoproteins) in women with preeclampsia. Am J Obstet Gynecol 1998; 178: 146-9.

3. WHO. The hypertensive disorders of pregnancy. World Health Organization technical report series 758. Geneva: World Health Organization, 1987.

4. Hussy H. Roiled B, Schjetlein B, Neshelm B-I, Berg K. High levels of LPG) lipoprotein in a family with cases of severe preeclampsia. Clin Genet 1996; 50: 47-9.

5. Robbers J. Redden COG. Preeclampsia is more than pregnancy induced hypertension. Lancet 1993; 341: 1447-51.

6. Utermann G, Kraft H, Mensile HJ, Hopferwizer T, Seize C. Hum Genet 1986; 78: 41.

7. Dahlon GH, Lipoprotein in cardiovascular disease. Am J Obstet Gynecol 1994; 108:111-25.

8. Begum K. Analysis of 2f1, 1.19 deliveries in Dhaka Medical College Hospital. Asia-Oceania J Obstet Gynaecol 1993; 19: 1-6.

9. Fauveau V, Koening MA, Chakroborty J: r Causes of maternal mortality in rural Bangladesh. Bull WHO 1980; 66: 643-51.

10. MacGillivray I; Rose GA, Rowe B. Blood pressure survey in pregnancy. Clin Sci 1969; 31: 395-407.

11. Christianson RE. Studies on blood pressure during survey in pregnancy. Am J Obstet Gynecol 1976; 125: 509-13.

12. deSwiet M. The cardiovascular system. In: Chamberlain HE. ed. Clinical physiology in obstetrics. $3^{\text {rd }}$ ed. Oxford: Blackwell Scientific Publications; 1991. p. 3-38.

13. Clarke SL. Control hemodynamic assessment of normal term pregnancy. Am J Obstet Gynecol 1989; 161: 1439-4.

14. Robson SC. Serial study of factors influencing changes in cardiac output during human pregnancy. Am $\mathrm{J}$ Physiol 1989; 256: 1060-5.

15. Littleton MD. Pregnancy hypertension: a systematic evaluation of clinical diagnostic criteria. PSG Publishing; 1977.

16. Page EW, Christianson R. The impact of mean arterial pressure in the middle trimester upon the outcome of pregnancy. Am J Obstet Gynecol 1916; 125: 740-6. 